\title{
Geochemical Characteristics of Two Types of \\ Carbonate Concretions of Chang 7 Member in the Middle-Upper Triassic Yanchang \\ Formation, Ordos Basin, Central China
}

\author{
JINGWEI CUI ${ }^{1}$, RUKAI ZHU ${ }^{1}$
}

${ }^{1}$ 1.Research Institute of Petroleum Exploration and Development, CNPC, Beijing, China, 100083

Carbonate concretion is an authigenic aggregation of minerals commonly found in sandstone and shale, especially in organic-rich shale. In the outcrop, large number of carbonate concretions developed in Chang 7 member in Tongchuan. Those concretions were studied in terms of stable isotope, clumped isotope to delineate its origin and sedimentary environment. Two types of concretions are identified. Type A concretions mainly distribute in organic-rich shale. This concretion was divided into the inner circular layer and the outer circular layer. In the inner circular layer, the value of $\delta^{13} \mathrm{C} \%$ (VPDB) is $9.98 \%$ o $14.19 \%$, and the value of $\delta^{18} \mathrm{O} \%$ (VPDB) is $-13.32 \%$ - $10.07 \%$. On the contrary, the $\delta^{13} \mathrm{C}$ and $\delta^{18} \mathrm{O}$ value of outer circular layer are $4.74 \%$ $0.59 \%,-17.86 \% \sim-15.59 \%$ respectively. The formation palaeotemperature of different parts of concretion ranged from 28.6 to $76.5^{\circ} \mathrm{C}$. This may be due to methanogenesis arising from bacterial activities in the fermentation zone, and the fractional distillation of carbon isotope of organic matter was caused by the methane bacterial activities. The calcite and dolomite spherulites in carbonate concretions may be due to the calcilization and dolomitization of cyanobacteria in the early diagenesis. The type B concretions were distributed in the fine sandstone, silty sandstone, and silty mudstone. The internal structure of concretions is uniform. The carbon isotopic values were negative, and $\delta^{13} \mathrm{C}$ was -5.019 $12.013 \%$, and the $\delta^{18} \mathrm{O}$ value was $-17.6 \sim 19.281 \%$. The value of ${ }^{87} \mathrm{Sr} /{ }^{86} \mathrm{Sr}$ was in the range of $0.710072-0.710392$. The temperature was established at $60.4{ }^{\circ} \mathrm{C}$ through clumped isotopes analysis. Based on isotopic analysis, the formation palaeotemperature at different parts of concretion was 55.4$65.6^{\circ} \mathrm{C}$. The origin of the concretion may be related to dehydroxylation in diagenesis, formed in the early-middle stage of diagenesis. 